\title{
A missing citizen? Issue Based Citizenship in City- Regional Planning
}

\author{
Jouni Häkli, Kirsi Pauliina Kallio and Olli Ruokolainen
}

\begin{abstract}
City regions are significant sites of economic development, policymaking, and everyday living. Yet in many countries they are weakly institutionalized and therefore lack established democratic practices. This article is based on a study exploring citizen participation in city-regional planning in Finland, where traditional participatory means have largely failed to invite and involve citizens. The analysis approaches city regions relationally, as evolving processes with a changing spatial shape and scope. Through the notion of lived citizenship, including the dimensions of status, practices and acts, the article reveals how the dominant ideas of citizenship in city-regional planning hide from view elements that are significant for citizen participation. Whereas people's rights to participation can largely be fulfilled on a territorial basis in municipalities and states through legal membership in political communities, in the context of weakly institutionalized cityregional planning such status-based forms of participation are typically not available. This vagueness has created an image of a missing city-regional citizenry, which the article sets out to challenge and rework through the notion of issue-based participation as lived citizenship.
\end{abstract}

\section{Introduction: city-regional planning and the missing citizen}

City regions have grown into important sites of economic development and policy initiatives. Their overall importance in shaping and framing societies has grown remarkably since the 1970s, and increasingly so over the past three decades (Scott, 2001; Davoudi, 2003; Parr, 2005; Rodríguez-Pose, 2008; Harrison, 2012; Jonas and Moisio, 2016). A significant element in the rise of the city region is urban and land use planning, where the focus has gradually shifted from cities, municipalities and neighborhoods to city regions. While the power relations between municipalities, regions, the state and city regions involve notable geographical variation, this shift has generated some fundamental effects on democratic societies, the role of citizens in urban development being one of them (Soja, 2015; Tomàs, 2015; Kübler, 2018; Lidström and Schaap, 2018).

City region is a vague concept, both academically and in practical terms. Tracing its variable nature, Rodríguez-Pose (2008: 1027) has identified some basic elements of city regions, some of which are in part contradictory. A common way to identify a city region is through a core city with functional ties to its surroundings, involving economic, housing market, travel-to-work, marketing and/or retail catchment factors. Yet the urban core can also be polycentric, as in networked mega city regions, and the boundaries of the hinterland are often indefinite and overlapping. Notably, city regions rarely match with existing administrative boundaries since, as Metzger (2013) portrays, they are continuous regionalization processes with a changing shape and scope. Concurrently, however, in practical contexts city regions continue to be defined in territorial terms. Planning practices commonly consider them as fixed areas (Davoudi, 2003; Healey, 2006), and research focusing on city regions can set out to compare them as measurable units (Lidström and Schaap, 2018). These interpretations reflect the popular use of the concept as referring to areal units consisting of specific municipalities and nested within a hierarchical scalar structure 'above' the city and 'below' the state. 
Haughton and Allmendinger (2015: 860, emphasis in original) propose that city regions are best understood 'as bounded and porous, territorial and relational', thus acknowledging the continuing relevance of regional organization but paying attention to the processes and connectivities through which the world works (Healey, 2006; Metzger, 2013; Jonas and Moisio, 2016; Wu, 2016). In this regard, the planners' and policymakers' insistence on neighborhoods and other planning spaces as definite areal entities signals a bounded and territorial understanding of city regions, whilst what actually happens in urban life and development processes underlines their fluidity. In our understanding, city regions do not form another 'layer' in the state-based spatial system. They instead grow in between, within and beyond the territorial organization of the state, through relational connections and disruptions following particular logics, largely economic but including also socio-cultural elements and political steering. Interested particularly in the democratic dimensions of such city regionalizations, we ask how citizenship should be understood in the relational framework, and how citizen participation can be part of city-regional planning.

The empirical context of this article is Finnish city-regional planning. In Finland, urban planning is largely implemented through the statutory planning system, by municipalities and formal regions, yet it is accompanied by a variety of strategic planning practices including an increasing amount of city-regional initiatives. They are encouraged by the state through structural city-region schemes, mobilized in the form of agreements on land use planning, housing and traffic, and currently also linking in services and business. The idea of these 'MAL-agreements' is to inform statutory planning by creating visionary schemes of city-regional development with the largest Finnish cities as their cores, and concurrently to act as reminders of shared aims by the municipalities involved. Importantly from our perspective, as these are not binding strategies or agreements, they are not regulated by the legislation that rules statutory planning processes. As a result, many democratic elements of urban planning tend to be overlooked, and citizens have little role in city-regional envisioning or in the following development processes. Besides problems of legitimacy, city-regional planning then also fails to take advantage of the mundane knowledge that citizens accumulate in their daily city-regional lives.

The article proceeds as follows. We begin by introducing our conception of lived citizenship as multi-faceted agency, including the elements of status, practices and acts as outlined by Engin Isin. Rather than seeing citizenship as a fixed set of rights, this approach seeks to account for 'the meaning that citizenship actually has in people's lives' (Hall and Williamson, 1999: 2). Next, the idea of issue-based participation is presented, as a potential approach to recognizing and building opportunities for lived citizenship in the context of city-regional planning. After this, we provide a brief description of the research project, including research methods and materials, and the context of the study. In the next sections, we present an analysis of city-regional citizenship based on our study with practical city-regional experts. We conclude by proposing an approach that notices issuebased participation as a relational form of political agency, and present some practical implications of how lived citizenship could be mobilized in democratic city-regional planning.

\section{Multi-faceted (city-regional) citizenship}

The question of city regions as transforming contexts for citizenship has intrigued urban and regional researchers for more than two decades (e.g. Garcia, 1996; Smith and Guarnizo, 2009; Soja, 2015). From early on, scholars have noted how the globalization of economic and political processes has challenged the state as the sole provider of rights embedded in citizenship as a legal status, and how urban political life increasingly is about rights being claimed in and through social practices that mark a substantive (not formal) citizenship (Appadurai and Holston, 1996; Isin, 2000). Hence, rather than a matter of scaling citizenship 'down' to city-regional level, the very notion has been subject to 
redefinition that complicates the spatiality of citizenship, and recognizes altogether new urban citizenships as politics whereby 'people struggle to meet the heady demands of daily urban life' (Jonas and Ward, 2007: 174).

More recently, the discussion on city-regional citizenship has gained further nuances as scholars have sought to find a language that allows them to address various kinds of rights to belonging and participation in the appropriation of cities as lived environments and sites of politics. That people's orientations and concerns increasingly escape the territorial confines of singular municipalities or urban jurisdictions, and are embedded in practices and experiences of everyday life, have been captured with notions such as 'metrozenship' (Yiftachel, 2015), 'lived citizenship' (Lister, 2007), and 'communities of affected interests' (Barnett, 2017). While research on city-regional citizenship is relatively scarce, there is a growing body of research that seeks to make sense of urban forms of attachment, claims making and agency that cannot be pinned down to territory or legal status in any simple or straightforward manner (Häkli and Paasi, 2003; Purcell, 2007; Aldred, 2010; Jones, 2012; Kübler, 2018; Lackowska and Mikuła, 2018; Lidström and Schaap, 2018).

Building on this work, we approach the question of city-regional citizenship through the notion of 'lived citizenship' so as to capture the rich variety of political roles, practices and agencies that people engage with in urban life. Adding to the established notions of lived citizenship, based on the preliminary insights by Hall and Williamson (1999) and Lister (2007), and developed further by Rubin et al. (2014), Wood (2015), Kallio et al. (2015), De Carli and Frediani (2016) and Pascucci (2016), among others, we follow Engin Isin's (2008) understanding of status, practices, and acts as the three dimensions of citizenship (also Staeheli, 2011; Häkli, 2018). To us, lived citizenship is the contextually specific enactment of these dimensions of citizenship in people's everyday life.

Citizenship status refers to the legal recognition of rights and responsibilities based on membership in a territorially defined political community, primarily the state but in many countries also the region and the municipality (e.g. Fahrmeir and Jones, 2008; Lidström, 2010; Bauböck, 2017; Gargiulo, 2017). Typically, the lack of citizenship status means very limited opportunities to participate in the public life of a polity. Seen as practices, citizenship is about the enactment (or denial) of citizenship rights in specific contexts and settings. These formal or semi-formal practices are derivatives of status and include, for example, voting in elections, participation in demonstrations, and expressing public opinion.

Acts of citizenship captures political activities that go beyond practicing a citizenship status in an institutional, public or organized setting. According to Isin (2009: 371), acts create new sites of struggle alongside the already existing arenas of citizenship, thus challenging, reworking and reinventing established relationships between politics, citizenship and the boundaries of political community (e.g. Staeheli, 2011; Leitner and Strunk, 2014; Kallio et al., 2015). This dimension of citizenship resonates strongly with feminist-inspired scholarship that accentuates citizenship as learned and taught, allowed and denied, and enacted in the personal and informal spaces of daily living together (e.g. Kallio, 2018a). To complement these approaches, in the city- regional context it seems particularly important to identify how such mundane political agency is, and can be, connected with the more formal dimensions of citizenship that dominate in urban planning and other city-regional political and administrative processes.

Thus understood, we find lived citizenship a particularly useful analytic prism for approaching participation in city-regional planning because, in most countries, it is weakly institutionalized and lacks many of the characteristics that would support citizenship as practiced through formal or semi-formal channels (such as the mandatorily organized participation in the planning of land use in 
Finland, see below). We place our arguments mostly in the Western urban context, but interesting resemblances can be found with city-regional developments in other parts of the world, for example in China (Wu, 2016) and urban Africa (Beall et al., 2015). Wu's (2016) critical portrayal of the statesteered city-regional development in China emphasizes that in question is, importantly, a process of scalar restructuration where the globalizing large cities act as drivers for national development, at the same time deepening regional and local inequalities within China. Beall et al. (2015) draw attention to the development of mid-sized city regions in Africa, pointing to their super-diversity that involves certain specificities in comparison to Western urban development (e.g. inconsistency in urban planning and regulations, combination of different traditions of leadership), largely unknown to the international scholarship that, thus far, has taken little interest in African urbanization beyond the major cities.

It is precisely the status of city regions as 'fluid, diverse and characterized by difference' (Harrison, 2007: 323) that makes them more or less unrecognized and amorphous political communities. In this regard, they remain largely overshadowed by the legally recognized national citizenship that typically mobilizes through representative democracy, as well as local citizenship and rights to participation based on people's residence in municipalities (associated with the city region). Taking distinct forms in different parts of the world, urban life increasingly exceeds and transgresses the boundaries of single municipalities and state borders, as people's places of residence, arenas of transactions and business (including virtual), and political engagements branch out. Instead of becoming 'less local' or 'more national', in current societies many people develop translocal lives, often including transnational elements, due to diversified living conditions and mobile lifestyles. From this tension between de facto city-regional life and de jure municipal and national citizenship, there follow interesting questions, as well as practical problems, related to the possibility of people participating in city-regional planning and development processes.

One key issue is how to determine who should have the right to have a say in city- regional planning, under the circumstances of weak institutionalization of city regions and the concomitant unclarity of how (informal) planning processes are politically directed, publically controlled and legitimized. In this context, approaching citizenship from the viewpoint of agency-involving acts in parallel with status and practices--is a necessary condition for seeking an answer because it helps in expanding the scope of legitimate participation. After all, Isin (2009) proposes that we can act as citizens in a way that challenges and reworks given statuses and prevailing practices. Yet it is not a sufficient condition in that it says little about who exactly is to be included and on what basis. Indeed, why is democratic participation relevant in the city-regional context in the first place? The question is problematic because, as mentioned, city regions typically lack clear institutional mandates for participation, which marks them off from municipalities and statutory planning procedures. The question then remains, what justifies the idea of a political community that exceeds the limits of established and legally recognized polities, such as municipalities, nation states and supra-national political unions?

In seeking a tentative answer, we have found the principle of 'all affected' helpful. Developed in the context of different traditions of political philosophy and democratic theory, mainly to address the optimal composition of democratic polities, the principle states that 'all who are affected by a decision should have a right to participate into making it' (Dahl, 1970: 64). Thus, everyone affected by a certain city-regional planning process can be considered a (potential) citizen. While we agree with the critiques that claim the principle to be too indeterminate and elusive in regard to who is to be included in a process of deliberation and decision making (e.g. Lagerspetz, 2015; Barnett, 2017), we nevertheless find it an important spring board towards a more grounded conception of city- 
regional participation, as this article will later discuss in a specific empirical context. Moreover, we take 'all affected' literally as a principle, not a mechanism for decision making in actual situations (which many critiques seem to imply; see for example Agné, 2006). Seen as a principle for inclusion in situations characterized by institutional ambiguity, the problems of which need to be specified contextually, the all-affected principle works well in opening the field of participation towards acts of citizenship. In the next section, we turn to the idea of issue-based participation as one possible means with which to specify it.

To sum up, although citizenship remains institutionally and territorially grounded to some extent, its enactment is not fixed to territories or institutional arrangements only. Citizenship also actualizes through experiences, interpretations and acts in people's everyday lives, in a way that cuts across the borders of existing polities. Our emphasis on lived citizenship as a versatile political participation opens up possibilities for examining city-regional participation as processes where people are not involved only through their status as municipal residents or legal members of the nation state, but also as partners in solving the puzzles of city-regional planning. While this notion expands the idea of citizenship, it does not suggest that new forms of citizenship ought to replace the established ones. Rather, as translocal and transnational developments are strongly shaping urban life, it is important to identify how people-as democratic subjects—situate in this transformation where states and municipalities remain important players.

\section{Shifting the focus: from planning processes to politicized issues}

In a recent article, Jonathan Metzger (2013: 1378, emphasis in original) argues that 'the emergence of a regional public is a process in which issues are put on the table', referring to loosely knit regional stakeholder communities that: need not be limited to only laypersons living in the proposed region, as defined in Euclidean space, and is not even limited to individuals-but may rather consist of all sorts of geographically dispersed networks and organizations ... who become topologically rather than topographically attached or caught up in a regionalization process generated by the issue--either by way of their own deliberate actions or commitments, or as the consequence of the purposeful or unwitting activity of others.

In a similar spirit, Leino and Laine (2011: 99-100) argue that theoretical discussions on urban planning and public participation have largely ignored the pragmatist principle that people get involved when interested in a particular issue, not the planning process itself. Both arguments are inspired by Latour (2007: 815), who has stated that we should figure politics around issues instead of bringing issues into a ready-made political sphere, and Marres (2007: 775), to whom the articulation and definition of issues form an essential part of public participation and democratic practices.

In agreement with these scholars, we propose that in democratic city-regional planning the focus ought to be shifted from inviting people living in the region to comment on regional plans, to discussing regionally pertinent issues with people who have things at stake in them, regardless of their residence, workplace or other status. Concretizing the notion of lived citizenship, this idea of issue-based participation is connected with a relational conception of city regions-not as clearly defined territories with static forms of government and established democratic structures, but as transforming constellations with a changing shape and composition.

Moreover, to be truly democratic, city-regional planning needs to encompass the politicization of issues as an integral part, to leave space for diversity and divergence, new openings and debate, and citizen-initiated change (Kallio and Häkli, 2017: 99). With this, we do not suggest a move towards 
self-organizing systems and action where giving responsibility to citizens and their collective associations runs the risk of endorsing elites and active citizen groups at the expense of other dwellers, and where the withdrawal of public actors may open opportunities for new powers to exert their needs and values over others (Savini, 2016; also Kallio, 2018b: 583). While such modes of internal change aim at the empowerment of citizens and democratization within complex urban systems, they often lead to biased outcomes (e.g. Peck, 2012; Swyngedouw, 2010). Instead, we propose the development of dialogic relations between city-regional planning and citizens, formed around topical issues, the relevance of which is recognized from both directions, and allowing for politicization from various perspectives and actor positions.

The potential of issues in generating citizen participation and mundane political agency has been explored in the fields of communication and new media studies (e.g. Dayan, 2005; Habermas, 2006; Kim, 2009; Bennett and Segerberg, 2012; Shklovski and Valtysson, 2012; De Lange and De Waal, 2013). One premise in this work has been that, with limited motivation and resources to focus on generally politicized matters, people are inclined to direct attention to issues that concern or interest them the most. This attunement is likely to reflect being affected by the issue, either in the sense of having an interest or taking an interest in it, thus forming the basis of politically oriented agency, or 'becoming political' (Häkli and Kallio, 2018).

Habermas (2006: 420) describes how people come to form and share political awareness and attitudes as part of their everyday mediated living, by picking up bits and pieces of casual information and linking them to one's existing understanding without necessarily holding much knowledge about topical political processes or systems. This is not to say that people could not possess relevant professional knowledge, or gather understanding about ongoing administrative processes and public debates while developing political views and agencies. Lidström's (2010) findings for instance suggest that this is rather likely in contexts of city-regional development and planning as the interested citizens tend to be highly educated. Kim (2009: 257-8), however, emphasizes that being part of the elite does not exhaust the idea of issue-based politics. Echoing Habermasian tone, and placing her arguments in variable social media environments, she accentuates that regardless of their background or social position people can identify issues of particular import, form oriented stances in regard to them, and take action as the opportunity arises (also Shklovski and Valtysson, 2012).

Opportunities to articulate views based on practical citizen knowledge, and taking action when this knowledge can be influential in city-regional planning, forms our focus in exploring the potential for enhancing democracy in city regions through citizen participation. Working with the notion of lived citizenship, we consider it as a multi- faceted form of political agency that comprises not only statusbased and practiced citizenship but also issue-based acts that partake in challenging and reworking the relationships between politics, citizenship and the political community. To study such forms of participation more concretely, we next move to discuss our recent research with city-regional planning experts. Drawing from interviews with them, we first assess the degree to which planners and practitioners are able to identify citizens as (potential) participants in city-regional planning; we then explore their views on existing practices of citizen participation; and finally we discuss how specific issues may draw in potential people affected by them, that is, those who have or take an interest in the issues at stake.

\section{The study and the Finnish planning context}

The Finnish policy landscape where we explore citizen participation is firmly based on a statutory planning system. However, the past decade has witnessed various informal (strategic) practices 
emerging in Finnish spatial planning, as is the case in many other European countries (e.g. Healey, 2009; Lidström and Schaap, 2018). Statutory land use planning is regulated by the Finnish Land Use and Building Act (1999) that also rules on citizen participation as a mandatory part of the planning procedure. The planning system has three tiers: the national land use guidelines provide a general planning frame set by the Finnish Government; the guidelines are concretized in formal regional land use plans approved by regional councils; and the most detailed planning takes the form of local master and detailed plans prepared and approved by municipalities (Ministry of the Environment, 2018). With the municipalities' strong self-governance and planning monopoly over their jurisdiction, the local plans have a major role in shaping the actual urban environment (e.g. Bäcklund and Mäntysalo, 2010; Leino and Laine, 2011; Hytönen, 2016).

However, alongside the statutory planning system, new forms of strategically oriented and perhaps more 'agile' informal, ad hoc and contract-based forms of land use planning have emerged, especially around important urban centers (Bäcklund et al., 2018). The most prominent new cityregional planning practices are structural schemes and the so-called MAL agreements on land use, housing and traffick (in Finnish maankäyttö, asuminen ja liikenne, MAL). Structural schemes function as tools for coordinating municipalities' land use, as well as for visioning the city-regional future from a land use planning perspective. In this sense, they are non-statutory plans that document the goals and land use outlines transgressing the borders of individual municipalities. They also work as one basis for the aforementioned MAL agreements, through which the state seeks to achieve nationally set goals, such as the densification of urban fabric or balanced social housing. The agreements aim at overcoming individual municipalities' suboptimization in their planning and development activities by committing municipalities to city-regional goals. The national government, for its part, agrees to co-fund for example major traffic infrastructure projects that pertain to the city regions (Mäntysalo et al., 2015). Both structural schemes and MAL agreements are predominantly expert-led forms of planning with only indirect connection to representative decision-making processes in the municipalities' political bodies.

Two kinds of ambiguity result from the dualistic structure of the current planning system in Finland. First, it is not always clear how the statutory land use planning relates with the more visionary cityregional planning that, while being less formal, creates guiding conditions for the former. Concerns have been raised about the transparency and legitimacy of city-regional planning that is mainly about informal and relatively exclusive intermunicipal cooperation between land use and other planning experts (Bäcklund et al., 2018). Second, as the city-regional planning operates on a nonstatutory basis, it lacks clear procedures for citizen participation that the Finnish Land Use and Building Act (1999) guarantees in municipal planning processes. Hence, the new practices are left to include citizens in ways and to an extent that the practitioners deem suitable in each case. In a recent study, we have explored the consequences and challenges that these ambiguities set for arranging and developing citizen participation in city-regional planning.

The article draws from a research project 'Beyond MALPE Coordination: Integrative Envisioning', exploring democratic elements of planning in Finnish city regions, and specifically, the possibilities of citizens to know about and present their views on strategic development trajectories. The empirical study included a documentary analysis, the analysis of previously collected interview data, thematic interviews, and participatory research with professionals currently involved in various city-regional planning and development processes. In this article we analyze interview materials collected in the project, including in-depth interviews with 26 specialists from the fields of land use planning, housing, traffic and economic development (transcribed and anonymized). The interviewees were selected with a snowball method, facilitated by the Finnish MAL network 
coordinators. Each participant--or the organizations they represented-had taken part in or influenced a MAL agreement process, including administrative staff in the key ministries and other national bodies, and key actors from the four biggest city regions in Finland, forming around Helsinki, Tampere, Turku and Oulu. The interviews were organized so that we first talked about general themes on city-regional planning and development, and then moved on to the themes of citizen participation and democracy. As the latter themes were not brought up in the invitation letter or mentioned at the beginning of the interview, we were able to identify how matters related to citizen participation and democracy were spontaneously taken up by the professionals, and how they were discussed in response to our queries.

Some of our participants had long-term expertise in city-regional policy; some of them were practitioners concretely involved in city-regional planning, and others had acted in different roles related to urban planning. The combination provided us with a rich set of data. After a preliminary analysis, we discussed the results with various professionals in our knowledge co-production workshops. In addition to providing further insights and producing practical results, the workshops confirmed that the interview material describes rather well the current situation of citizen participation in Finnish city-regional planning.

\section{Recognizing city-regional citizens}

The following analysis sheds light on how professionals working with city-regional development recognize, first, the lack of citizenship or the awkward position of citizens; second, the citizens who currently participate in city-regional processes and make use of the existing participation opportunities; and third, the citizens who could, or perhaps should, be included through new kinds of citizen participation opportunities, yet the means for doing this are largely missing.

\section{- $\quad$ The missing citizen}

When responding to our questions concerning citizen participation in city-regional planning, the interviewed experts mostly talked about municipal citizens or residents, whose interests mainly related to local issues, including nimbyism (acronym for 'not in my backyard', meaning an attitude by citizens who oppose a project or an initiative near their place of residence). Two of the participants stated:

\footnotetext{
They are interested in local questions only. I have never seen anyone taking up the question of why climate change is not taken seriously enough, for example. Those forms of political activity exist elsewhere (state administrative official).They are concerned with snow being piled on the neighboring lot, or a railyard. The focus is on 'my surroundings'. Citizenship seems to disappear, from an agency point of view. I don't think that an average municipal citizen can conceive of the whole (municipal planning official).
}

As these examples imply, citizens do not seem to fit in the city-regional framework as their concerns take place on a different scale, mainly the neighborhood and municipality: 'It is difficult for the municipal citizen to figure out regional planning, it is so far from their everydayness' (municipal planning official). This conception aligns with the idea that citizen participation ought to be dealt with by municipal actors: 'The municipality is, after all, closer to people's everyday life while we here may be pretty far from that' (state administrative official).

Yet some of the professionals involved in actual planning processes agonized about the situation. 'We constantly think about ways in which to raise the residents' interest on the regional level, as it is so challenging' (city-regional planning official). Another participant stated: 'We have organized some residential events but as we talk about matters on that scale ... about such big issues, it is a 
rather small percentage of residents who can participate in them' (municipal planning official). The dilemma was stated again by yet another interviewee: 'Residents are particularly challenging because this is so strategic' (city-regional planning official). Thus, one participant suggested, 'Communication should be emphasized. If we talk about regional and community structures, we lose the attention of $99 \%$ of people right away, immediately' (regional planning official).

Characteristic of this line of thinking is that people are approached as residents, which fixates them territorially to the neighborhood and the municipality, and hides from view other possible affiliations that people may have as citizens. This is cross cutting throughout the first part of the interviews where the participants took up democracy issues spontaneously. For example, when experts talked about future housing, they considered citizens in relatively passive roles, as residents concerned with their immediate surroundings only (see also McClymont and O'Hare, 2008):

If you think about the nimby phenomenon-when we are planning a new residential area, the ones who react are those at the surroundings, not those who will be using the area at some point. We don't even know who they are (city-regional planning official).

Thus, citizens remain stuck in status-based citizenship attached to their residence in municipalities, today and tomorrow. Alternative citizen roles, building through political orientations, moral and ethical stances, lifestyles, education and working life, or personal interests and hobbies are not considered as potential starting points for participation. Moreover, city-regional matters are placed 'above' the everyday scale of living, on a strategic level that lies somewhere beyond common reach. Understanding the latter is said to require professional knowledge and deep engagement from citizens interested in taking active stances:

These are general level abstract matters. If they can't really grasp what the land use framework is, even what it means, it does not encourage people to participate ... It requires commitment to make sense of these kinds of documents and organizational frameworks. And as some of them do not lead to actual decisions, it is somehow awfully demanding (city-regional planning official).

Together these aspects mean that citizens—and the issues significant from their perspectives-are relatively invisible in city-regional planning. The missing citizen is well recognized, with variation in whether the present situation is seen through democratic deficiency or as an accepted state of affairs. The dimension of lived citizenship dominating this recognition is status by which people are identified as non- city-regional citizens. Bluntly put, for many experts the conclusion is that cityregional participatory efforts go to waste, as there is no citizenry capable of responding to them. This leads to either considering the question of citizenship irrelevant or seeking better participatory tools for engaging people.

The active citizen

Most of our participants knew about, or had been organizing, citizen participation activities, including surveys, questionnaires and barometers, events where preliminary plans are introduced to citizens for feedback, and consultation of interest groups at different stages of planning. As cityregional planning is not part of the formal planning system in Finland, but closely linked with it, the actual planning outcomes are approved and legitimized in the representative democratic bodies of (some of) the municipalities involved. This allows the city-regional actors to concentrate on direct forms of participation at their discretion. Yet, professionals have identified challenges in these forms of participation, whether concerning broad development processes with large target audiences or more specific plans with select invited participants.

Regarding surveys, one of the participants claimed that 'certain generations do not respond at all' (municipal planning official), while another interviewee conveyed that it is 'terribly hard to build a 
questionnaire that would produce a citizen voice' (municipal planning official), pointing again at the dilemma of the missing citizen. Apparently, as people do not consider themselves as city-regional citizens, they are ill motivated to respond to queries about the city-regional services offered to them. Indeed, many large-scale surveys approach people as customers or service users whose opinions are input for developing public transportation, public amenities or the provision of commercial services. This does not necessarily appear to people as opportunities to citizen participation even if it can be regarded as a form of active citizenship in the new public management era (Bäcklund et al., 2014).

When talking about participatory events where citizens are invited, our interviewees were close to unanimous. Attendance tends to be low with only the usual suspects showing up, which makes the citizen voice rather biased:

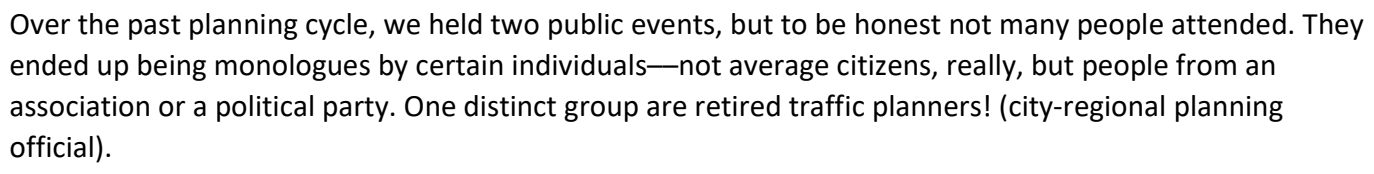

We had an event for residents, for instance, but only some active people from NGOs came, whom we meet anyway, no average citizen came to say anything (municipal planning official).

Many professionals are pulled between two stances on this kind of active participation. On one hand, they feel that the people who have plenty of knowledge and good capacities to converse on city-regional planning issues can provide useful insights. On the other hand, they find public events pointless if they only bring in the most active people who get involved anyway. Also, some professionals are concerned with the bias that may result from including such active citizens' voices in planning processes, echoing the dangers identified in self-organizing urban systems: 'It may be that residents don't even wish for balanced housing areas, at least some privileged people, if you asked them it could lead to the deepening, not easing off, of segregation' (state administrative official) (cf. Savini, 2016).

In terms of lived citizenship, the current forms of city-regional participation are attuned to people who are good at practicing their citizenship status through democratic systems, and can make use of different opportunities to express their opinions on planning issues. The most active citizen groups are capable of presenting their case, both personally and with various associations, on different planning scales and through a variety of forums, thus participating in city-regional planning as rights-bearing subjects through the formats offered to them. This places emphasis on those issues that appear relevant to select citizen groups, and runs the risk of overshadowing other citizens' perspectives.

\section{- $\quad$ The issue-based citizen}

The third dimension of city-regional citizenship identified by our participants turns the gaze away from the planning system toward the lives that people lead. In this perspective, the professionals do not find it difficult to appreciate people as city- regionally interested knowers and doers. 'We have the average Joe here, a father of two children who lives here, goes to work there, the kindergarten is that way, and where does he do his shopping ...', an ordinary city-regional life situation described by one participant (state administrative official). Another professional claims that '.. because in any case, people are interested in matters, they are interested in what happens with their close ones and in their neighborhoods, how their children and elderly parents are doing, and so on'. Thus, she continues, 'We should formulate questions so that it is easy for people to have their say' (state 
administrative official). Similarly, another interviewee accentuates the importance of 'scaling matters to human size' (state administrative official).

What our interviewees refer to as matters or questions pertinent to citizens, we conceive of as issues, around which participation could coalesce. Examples of how city-regional dwellers already act in influential ways, beyond formal structures and organized participation activities, were identified mostly from vivid social media discussions, specifically the More Urbanity to Helsinki [Lisää kaupunkia Helsinkiin] movement. Such civic activities were seen as an interface between formal and mundane citizenship:

\begin{abstract}
Anyone can establish a Facebook page for discussing the urban structure of the Helsinki region. If it generates enough conversation that gains weight, it will have an influence on political decision-makers and their attitudes. In the context of zoning, there is the 'More Urbanity to Helsinki' Facebook group that engendered a huge amount of discussion during the preparation of the zoning plan, with a link to decision making-council and committee members were reading the discussion, and it was influential in that way (municipal planning official).
\end{abstract}

The movements requesting more urbanity, first in Helsinki and later in other cities, present an example of issue-based citizenship where people participate in the actual politicization of topical issues in urban planning from their own starting points. Participation in this kind of informal bottom-up activity does not entail a certain status, like residence or legal position, or participation opportunities organized by a public actor (Bennett and Segerberg, 2012; Shklovski and Valtysson, 2012). What counts are motivation and capacities to contribute to the discussion, and the recognition of these views among the debaters (Dayan, 2005; Kim, 2009; De Lange and De Waal, 2013).

Beginning from these thoughts, some participants envisioned how people could be approached in new ways, especially through issues related to traffic, transportation and mobility at large. This focus is hardly surprising as mobility is not only one key element in the planning of well functioning city regions, but also a concrete and familiar matter to all city-regional dwellers (e.g. Wickham, 2006; Spinney et al., 2015). Tying together neighborhoods, business districts, working places, green spaces, and public and private services, traffic networks and transportation infrastructures span across municipal boundaries. 'Running errands, going to work and hobbies-they surely don't follow any borders', noted one of our participants (state administrative official).

Mobility-related issues were regularly brought up by the professionals as fruitful contexts for dialogue with citizens, particularly in contrast with housing and land use planning issues that were deemed more abstract and difficult for the 'average citizen' to fully grasp. As one participant stated, traffic often produces emotionally charged personal experiences and attitudes, such as 'Jammed every day! Damn cyclists! Damn motorists!' (regional politician). People may also find planning processes related to transportation noteworthy as the outcomes directly touch upon their everyday living: 'Talk about how I will get to work, how the transport links will be resolved, will the beltway connections be established-deeply felt issues related to the everyday region' (state administrative official). This broad interest has been mobilized in some participatory practices, mainly in the form of public transportation questionnaires and feedback systems. The results have been useful even if limited to people's immediate experiences about the routes and forms of transportation that they personally use, and not including their views about the transportation system more broadly. Yet, in the context of inter-municipal organization of public transportation, it has been possible to interpret people's mundane views city-regionally so that experiences coming from people living in different areas are contrasted: 
People at the outer rim think this way, people at the urban core think that way. This is the most valuable data to us. I don't know how the residents feel about [the questionnaires] but they serve the service development best (city-regional planning official).

The utility value notwithstanding, from the lived citizenship point of view, these kinds of participatory practices have shortcomings. Most importantly, the framing of the issue and the questions asked are decided by the transportation planning experts, and hence the process leaves little room for citizens to politicize mobility-related issues. For a progressive step forward, some interviewees proposed facilitated discussions on issues affecting the city region as a whole, or otherwise reaching beyond people's immediate concerns. The facilitative role of planning experts would be to 'translate' strategic planning issues from professional terminology into generally accessible form and language, thus leaving space for citizen-generated ideas while framing the discussion in a meaningful way from the planners' point of view. This would offer more nuanced and open opportunities not only for gathering feedback but also for learning about citizens' views.

It needs to be pretty well moderated, someone giving options. If you just sit down and start talking, it rarely leads to much. But if you begin like 'We have these two options', it gets things going (municipal planning official).

But who should be invited to such discussions, and how? One possibility that our analysis reveals is to turn to interest groups that are already organized, or are in the process of emerging, around an issue. While the participation of interest groups is among the common forms of active citizenship, our participants envisioned new angles coming from associations with city-regional activities, such as semi-organized cyclist groups.

\footnotetext{
It mainly comes through associations, somehow they have the knowhow and capacities to participate in such ways (municipal planning official). We have an 'everyday cyclists association' that makes constantly good propositions ... You need to leave them space so that it does not get too formal and concurrently accept that they have plenty of such expertise that necessarily I don't have, and we do not have in the system (municipal planning official).
}

While mobility issues were seen as opportune for citizen participation, some of the interviewees thought that citizens have ideas only on the micro level and they get lost when moving to a broader picture: 'When we take up specific transportation projects or cycling or something like that, we may get a whole flood of comments, whilst on the level of the whole plan, nothing' (municipal planning official). However, others gave due recognition to city-regional citizens' capacity to contribute to broad planning principles, noting that they have no difficulties in conversing about key values and principles guiding planning processes, 'for example, issues like residential preferences and preferences in transportation' (city-regional official). While such discussions have their parallels in representational politics, they have particular value in the city-regional context in which political steering has a less clear role, and the politicization of issues is currently largely at the hands of professionals.

\footnotetext{
Knowledge about the future is partly visionary-what the future can be and what alternative pathways can be envisaged. In the plans, we indeed follow a certain vision to reach an ideal condition. But in the preparatory work, it is possible to weigh things up: what if this or that does not happen, what if something else comes up, what shall we do then? Perceiving alternative futures and changes is one key outcome of the processes. In this kind of scenario building you can involve basically anyone (state administrative official).
}

The most complicated context for including citizens in city-regional planning may well be the actual strategic work. However, following the all-affected principle we claim that all planning processes involve matters that potentially concern (all) citizens. The question that follows is, how can the professional knowledge of planners and the everyday knowledge of citizens be brought into a dialogue so that issues-not details or structures - can be placed on a common table? This, we 
think, is a key question in developing city-regional participatory practices that lean on people's experiences and mobilize the powers of their lived citizenship.

\section{Discussion: issue-based citizenship in city-regional planning}

The potential of mobility issues in citizen participation identified by our interviewees has also been noted in a recent study. Aldred (2010: 35) introduced the notion of 'cycling citizenship' as an embodied practice that challenges the static image of a status-based citizen. While she does not associate it directly with inter-municipal practices or city-regional agency, she analyses cycling in relation to other forms of traffic, such as private cars and their users, and finds different forms of transportation interlinked with the formation of citizen agencies (also Green et al., 2012; Spinney et al., 2015). Studying cycling as a political practice in late nineteenth century Britain, at a time when women were not citizens in a legal sense, Jungnickel (2015) proposes women's experiences of cycling, and other people's related reflections, as the becoming of a new kind of citizenship. In his research on public transport, Wickham (2006: 24$)$ found that by making it possible for people to move, public transportation systems enable urban citizenship and tie a city together as a political space. Lidström (2006: 879) has shown that commuters may be aware of politicized issues within a city region, with interests and agency reaching beyond their residence. Focusing specifically on cycling commuters, Van Duppen and Spierings (2013) draw attention to how they make sense of the city as a whole, which they argue is poorly acknowledged in urban planning. In addition, the study by Jones (2012) describes some acts of minor resistance by commuter cyclers which impact on the urban fabric.

While we recognize the good potential of mobility-related issues to engender new participatory practices in city-regional planning, we hasten to emphasize that there are other dimensions of urban life that may well turn into issues of similar translocal appeal. Our own analysis brought up people's quest for more urbanity and the role of social media in citizen-led participation. Other studies describe a spectrum of issues, such as self-organized urban gardening, local energy production, public infrastructure, creating sustainable food chains, ownership of the city through urban new media, among others (Rosol, 2010; De Lange and De Waal, 2013; Sawhney et al., 2015; Feldhoff, 2016; Reed and Keech, 2019). Any issue that gains weight in people's everyday lives, and may be notably influenced by long-term city-regional plans, involves potential for emerging cityregional citizenship, and for the politicization of issues on a city-regional scale.

Issue-based participation, as discussed in this article, is premised on the idea that citizens are not identified or heard on a territorial basis (e.g. citizenship as a status based on residence), and their democratic practice is dissociated from representative politics (e.g. practices of citizenship organized through formal systems and political parties). It also offers an alternative to neoliberal market-oriented participatory activities where citizens are placed in the roles of customers and service users, offering mainly opportunities to heavily formatted feedback. Instead, when people are encountered as city-regional citizens on an issue basis, their open-ended agency as citizens is emphasized. In this perspective, anyone engaged in the life of a city region is a potential contributor to city-regional planning when rightly addressed. Importantly, such open endedness involves spatial plurality and emphasizes lived citizenship as political agency, in contrast to static membership in a polity.

However, we also found that it is not easy for planning experts and professionals to see how people's mundane knowledges and activities could be turned into influential citizen agencies in cityregional planning--not just presenting residential views and feedback as service users, but also providing insights on strategic urban development. Similar observations have been made in studies 
on digital democracy (e.g. Douay, 2018; Wilson et al., 2019). Our participants explicitly recognized city-regional dwelling as a form of life, but had difficulties in apprehending city-regional citizenship as a form of political agency. We relate this to the fact that, in the conventions of urban planning, citizenship is still largely understood in terms of status and practices, rather than as proactive and surprising acts. In this perspective what people do, as city-regional dwellers, may seem non-political and weakly connected to the system world where planning takes place. Opening up and broadening the conception of citizenship, as we have done in this article, may hence be helpful in developing methods for translating between professional and mundane urban knowledges in city-regional planning, and thus politicizing urban knowledges in new ways.

Finally, we are aware of challenges related to biased citizen voices in the kinds of participatory efforts we propose. When discussing the case of citizen-initiated participation in urban planningthe 'More Urbanity to Helsinki' movement-many of our participants expressed concerns about certain voices, coming largely from elites and older generations, dominating the debate. While such voices may include progressive and insightful ideas, with potential to impact on ongoing processes, they cannot be given the prominence of the citizen voice. Thus, to avoid the pitfalls identified in the self-organization of citizen groups (e.g. Swyngedouw, 2010; Peck, 2012; Savini, 2016), we propose that citizens are invited to participate in ongoing planning processes when their practical expertise and issue-based views can be influential (e.g. envisioning when plans are taking shape, discussion on principles and alternatives). This way, specific efforts can be made to include people from various citizen groups that otherwise might be excluded. An example of how 'disqualified urban knowledges' may transform into an effective voice can be found from participatory projects with youth (e.g. Percy-Smith, 2016). Whereas this surely does not solve all questions related to the equality or effectiveness of citizen participation, our study indicates that it may help in involving a broader spectrum of citizens in large-scale planning processes, while allowing citizen knowledge to be sought in matters in which they have an interest.

\section{Conclusions}

In this article, we have explored the idea of lived citizenship in city-regional planning to capture a variety of roles, practices and agencies that form peoples' capacities and opportunities to participate and act politically. Our discussion draws from research on the democratic elements of planning in Finnish city regions, with specific focus on the possibility of citizens presenting their views on strategic development trajectories. In agreement with critical work on the all affected principle, we note that it is not possible to define clearly and in advance which citizen groups ought to be heard in city-regional planning processes due to their long time spans, spatial ambiguity, and the overall strategic nature of city-regional planning (Lagerspetz, 2015; Barnett, 2017). For the very same reasons, we deem it important to enhance citizen participation in these processes as, in Finland and elsewhere, they are more or less detached from the statutory planning system and thus not subject to all legislation on land use planning and urban development (Healey, 2009; Bäcklund and Mäntysalo, 2010; Lindström and Schaap, 2018). As city regions have grown into significant sites of economic development, policymaking, and the everyday life of people in the past 40 years or so, with their import still increasing, it is vital to draw attention to deficiencies in their democratic character and to their potential as arenas for citizen engagement (Davoudi, 2003; Parr, 2005; Harrison, 2012; Soja, 2015; Tomàs, 2015; Kübler, 2018).

In alignment with scholarship that identifies city regions relationally as continuous regionalization processes with a changing spatial shape and scope, we propose that understanding their complex geographies is helpful in conceiving why traditional participatory means often fail to invite and involve people in city-regional planning processes (e.g. Healey, 2006; Jonas and Ward, 2007; 
Rodríquez-Pose, 2008; Metzger, 2013; Yiftachel, 2015). These commonly result in either very biased citizen voices or meager outcomes, which cause frustration and skepticism among the professionals organizing participatory activities. On this basis, it is apparent that the traditional forms of participation leaning on the idea of status-based citizenship do not work well in the city-regional context. Whereas people's rights to participation can largely be fulfilled as legal members of municipalities or as residents in certain neighborhoods, city-regional life escapes such institutional structures and ordering. As city regions grow in between, within and beyond the territorial organization of municipalities and states, the people affected by the far-reaching plans and decisions often lack clear legal status that would link them to the planning process.

This vagueness has created an image of a missing citizenry. Our study shows that active citizens and city-regional dwellers are selectively recognized by experts and professionals involved in planning processes. People with expertise in, or dedication to, urban planning developments can contribute to them, and there are both individuals and collective actors who regularly do so. The experience and views that people gain in their city-regional lives are also apparent to planners, yet their connection to planning processes seems difficult to establish. What the participants in our study saw as a key problem is that people's mundane urban knowledge and the professional knowledge of planners is hard to piece together, which notably complicates the inclusion of citizens in strategic planning at large.

However, the professionals we interviewed were able to point out certain issues where this gap could be bridged. Issues related to traffic, transportation and mobility at large were mentioned most often as something people ponder about and struggle with in their everyday lives, while forming a key dimension in city-regional planning processes. What characterizes such issues is their recognized importance from both directions; that is, they are considered particularly significant by many citizens as well as professionals. Cycling, as a form of urban mobility, is one politicized issue that has already engendered issue-based participation with impact on city-regional planning, in Finland and elsewhere (Aldred, 2010; Green et al., 2012; Jones, 2012; Van Duppen and Spierings, 2013). We trust that other issues with such potential to generate public discussions and engagement can be identified in existing and future city-regional planning processes.

Perhaps we could envision strategic issue-based participation as a counterweight to expert-driven city-regional planning, with citizens coalescing around issues that are meaningful to them. This kind of participatory work could be organized as a dialogue between the needs of the planners and those of the interested citizens, provided that the professionals involved acknowledge the value of the citizens' practical knowledge for their ongoing work. Such an interaction might result in city-regional planning where certain planning issues meet with an issue-based citizenry of involved and active participants. While not providing answers to all problems of legitimacy or representation, it would be a constructive step towards acknowledging the citizens' everyday lived experiences, views and knowledges as complementary and positively challenging the planners' expertise and grasp of the city-regional big picture.

\section{Acknowledgements}

We wish to thank the handling editor and the three anonymous IJURR referees for a supportive process and helpful comments. We also thank the Academy of Finland for financial support, and the BEMINE project for an intellectual environment for our work (grant SA 303550). Finally, we are grateful to the Space and Political Agency Research Group (SPARG) at Tampere University for an inspiring research environment. 
Jouni Häkli, Space and Political Agency Research Group, Faculty of Management and Business, FI33014, Tampere University, Finland, jouni.hakli@tuni.fi

Kirsi Pauliina Kallio, Space and Political Agency Research Group, Faculty of Management and Business, FI-33014, Tampere University, Finland, kirsipauliina.kallio@tuni.fi

Olli Ruokolainen, Center for Cultural Policy Research, Pitkänsillanranta 3B, 00530 Helsinki, Finland, olli.ruokolainen@cupore.fi

\section{References}

Agné, H. (2006) A dogma of democratic theory and globalization: why politics need not include everyone it affects. European Journal of International Relations 12.3, 433-58.

Aldred, R. (2010) ‘On the outside’': constructing cycling citizenship. Social \& Cultural Geography 11.1, 35-52.

Appadurai, A. and J. Holston (1996) Cities and citizenship. Public Culture 8.2, 187-204.

Bäcklund, P. and R. Mäntysalo (2010) Agonism and institutional ambiguity: ideas on democracy and the role of participation in the development of planning theory and practice. The case of Finland. Planning Theory 9.4, 333-50.

Bäcklund, P., K.P. Kallio and J. Häkli (2014) Residents, customers or citizens? Tracing the idea of youthful participation in the context of administrative reforms in Finnish public administration. Planning Theory and Practice 15.3, 311-27.

Bäcklund, P., L. Häikiö, H. Leino and V. Kanninen (2018) Bypassing publicity for getting things done: between informal and formal planning practices in Finland. Planning Practice and Research 33.3, 309-25.

Barnett, C. (2017) The priority of injustice: locating democracy in critical theory. University of Georgia Press, Athens.

Bauböck, R. (2017) Citizenship and collective identities as political sources of solidarity in the European Union: the strains of commitment. In K. Banting and W. Kymlicka (eds.), The strains of commitment: the political sources of solidarity in diverse societies, Oxford University Press, Oxford.

Beall, J., S. Parnell and C. Albertyn (2015) Elite compacts in Africa: the role of area-based management in the new governmentality of the Durban City-region. International Journal of Urban and Regional Research 39.2, 390-406.

Bennett, W.L. and A. Segerberg (2012) The logic of connective action: digital media and the personalization of contentious politics. Information, Communication and Society 15.5, 739-68.

Dahl, R. (1970) After the revolution? Authority in a good society. Yale University Press, New Haven.

Davoudi, S. (2003) European briefing: polycentricity in European spatial planning. From an analytical tool to a normative agenda. European Planning Studies 11.8, 979-99.

Dayan, D. (2005) Mothers, midwives and abortionists: genealogy, obstetrics, audiences and publics. In S. Livingstone (ed.), Audiences and publics: when cultural engagement matters for the public sphere, Intellect, Bristol.

De Carli, B. and A.A. Frediani (2016) Insurgent regeneration: spatial practices of citizenship in the rehabilitation of inner-city São Paulo. GeoHumanities 2.2, 331-53.

Healey, P. (2009) City regions and place development. Regional Studies 43.6, 831-43.

Hytönen, J. (2016) The problematic relationship of communicative planning theory and the Finnish legal culture. Planning Theory 15.3, 223-38.

Isin, E. (2000) Democracy, citizenship and the city. In E. Isin (ed.), Democracy, citizenship, and the global city, Routledge, London.

Isin, E. (2008) Theorising acts of citizenship. In E. Isin and G.M. Nielsen (eds.), Acts of citizenship, Palgrave Macmillan, London and New York. 
Isin, E. (2009) Citizenship in flux: the figure of the activist citizen. Subjectivity 29.1, 367-88.

Jonas, A.E. and S. Moisio (2016) City regionalism as geopolitical processes: a new framework for analysis. Progress in Human Geography 42.3, 350-70.

Jonas, A.E. and K. Ward (2007) Introduction to a debate on city-regions: new geographies of governance, democracy and social reproduction. International Journal of Urban and Regional Research 31.1, 169-78.

Jones, P. (2012) Sensory indiscipline and affect: a study of commuter cycling. Social and Cultural Geography 13.6, 645-58.

Jungnickel, K. (2015) 'One needs to be very brave to stand all that': cycling, rational dress and the struggle for citizenship in late nineteenth century Britain. Geoforum 64 (August), 362-71.

Kallio, K.P. (2018a) Citizen-subject formation as geo-

socialisation: a methodological approach on 'learning to be citizens'. Geografiska Annaler B: Human Geography 100.2, 8196.

Kallio, K.P. (2018b) Not in the same world: topological youths, topographical policies. Geographical Review 108.4, 566-91.

Kallio, K.P. and J. Häkli (2017) Geosocial lives in topological polis: Mohamed Bouazizi as a political agent. Geopolitics 22.1, 91-109.

Kallio, K.P., J. Häkli and P. Bäcklund (2015) Lived citizenship as the locus of political agency in participatory policy. Citizenship Studies 19.1, 101-19.

Kim, Y.M. (2009) Issue publics in the new information environment: selectivity, domain specificity, and extremity. Communication Research 36.2, 254-84.

Kübler, D. (2018) Citizenship in the fragmented metropolis: an individual-level analysis from Switzerland. Journal of Urban Affairs 40.1, 63-81.

Lackowska, M. and Ł. Mikuła (2018) How metropolitan can you go? Citizenship in Polish city-regions. Journal of Urban Affairs 40.1, 47-62.

Lagerspetz, E. (2015) Democracy and the all-affected principle. Res Cogitans 10.1, 6-23.

Latour, B. (2007) Turning around politics: a note on Gerard de Vries' paper. Social Studies of Science 37.5, 811-20.

Leino, H. and M. Laine (2011) Do matters of concern matter? Bringing issues back to participation. Planning Theory 11.1, 89-103.

Leitner, H. and C. Strunk (2014) Spaces of immigrant advocacy and liberal democratic citizenship. Annals of the Association of American Geographers 104.2, 348-56. Lidström, A. (2006) Commuting and citizen participation in Swedish cityregions. Political Studies 54.4, 865-88.

Lidström, A. (2010) Citizens' intermunicipal political orientations: evidence from Swedish city-regions. Urban Studies 47.10, 2093-109.

Lidström, A. and L. Schaap (2018) The citizen in city-regions: patterns and variations. Journal of Urban Affairs 40.1, 1-12.

Lister, R. (2007) Inclusive citizenship: realizing the potential. Citizenship Studies 11.1, 49-61.

Mäntysalo, R., J.K. Kangasoja and V. Kanninen (2015) The paradox of strategic spatial planning: a theoretical outline with a view on Finland. Planning Theory and Practice 16.2, 169-83.

Marres, N. (2007) The issues deserve more credit: pragmatist contributions to the study of public involvement in controversy. Social Studies of Science 37.5, 759-80.

McClymont, K. and P. O'Hare (2008) 'We're not NIMBYs!' Contrasting local protest groups with idealised conceptions of sustainable communities. Local Environment 13.4, 321-35.

Metzger, J. (2013) Raising the regional Leviathan: a relational-materialist conceptualization of regions-in-becoming as publics-in-stabilization. International Journal of Urban and Regional Research 37.4, 1368-95. 
Ministry of the Environment (2018) Steering of land use planning: seeking a healthy and vital regional structure [WWW document]. URL www.ym.fi/en-US/Land_use_and_building/Steering_of_land_use_planning (accessed 23 October 2018).

Parr, J. (2005) Perspectives on the city-region. Regional Studies 39.5, 555-66.

Pascucci, E. (2016) Transnational disruptions: materialities and temporalities of transnational citizenship among Somali refugees in Cairo. Global Networks 16.3, 326-43.

Peck, J. (2012) Recreative city: Amsterdam, vehicular ideas and the adaptive spaces of creativity policy. International Journal of Urban and Regional Research 36.3, 462-85.

Percy-Smith, B. (2016) Negotiating active citizenship: young people's participation in everyday spaces. In K.P. Kallio and S. Mills (eds.), Politics, citizenship and rights, Springer, Singapore.

Purcell, M. (2007) City-regions, neoliberal globalization and democracy: a research agenda. International Journal of Urban and Regional Research 31.1, 197-206.

Reed, M. and D. Keech (2019) Making the city smart from the grassroots up: the sustainable food networks of Bristol. City, Culture and Society 16 March, 45-51.

Rodríguez-Pose, A. (2008) The rise of the 'city-region' concept and its development policy implications. European Planning Studies 16.8, 1025-46.

Rosol, M. (2010) Public participation in post-Fordist urban green space governance: the case of community gardens in Berlin. International Journal of Urban and Regional Research 34.3, 548-63.

Rubin, J.W., D. Smilde and B. Junge (2014) Lived religion and lived citizenship in Latin America's zones of crisis: Introduction. Latin American Research Review 49, 7-26.

Savini, F. (2016) Self-organization and urban development: disaggregating the city-region, deconstructing urbanity in Amsterdam. International Journal of Urban and Regional Research 40.6, 1152-69.

Sawhney, N., C. De Klerk and S. Malhotra (2015) Civic engagement through DIY urbanism and collective networked action. Planning Practice and Research 30.3, 337-54.

Scott, A.J. (2001) Globalization and the rise of city-regions. European Planning Studies 9.7, 813-26.

Shklovski, I. and B. Valtysson (2012) Secretly political: civic engagement in online publics in Kazakhstan. Journal of Broadcasting and Electronic Media 56.3, 417-33.

Smith, M.P. and L.E. Guarnizo (2009) Global mobility, shifting borders and urban citizenship. Tijdschrift voor economische en sociale geografie $100.5,610-22$.

Soja, E. (2015) Accentuate the regional. International Journal of Urban and Regional Research 39.2, 372-81.

Spinney, J., R. Aldred and K. Brown (2015) Geographies of citizenship and everyday (im) mobility. Geoforum 64 (August), 325-32.

Staeheli, L. (2011) Political geography: where's citizenship? Progress in Human Geography 35.3, 393-400.

Swyngedouw, E. (2010) Trouble with nature: ecology as the new opium for the masses. In J. Hillier and P. Healey (eds.), The Ashgate research companion to planning theory: conceptual challenges for spatial planning, Ashgate, Farnham.

Tomàs, M. (2015) If urban regions are the answer, what is the question? Thoughts on the European experience. International Journal of Urban and Regional Research 39.2, 382-9.

Van Duppen, J. and B. Spierings (2013) Retracing trajectories: the embodied experience of cycling, urban sensescapes and the commute between 'neighbourhood' and 'city' in Utrecht, NL. Journal of Transport Geography 30 (June), 23443. Wickham, J. (2006) Public transport system: the sinews of European urban citizenship? European Societies 8.1, $3-26$.

Wilson, A., M. Tewdwr-Jones and R. Comber (2019) Urban planning, public participation and digital technology: App development as a method of generating citizen involvement in local planning processes. Environment and Planning B: Urban Analytics and City Science 46.2, 286-302. 
Wood, B.E. (2015) A genealogy of the 'everyday' within young people's citizenship studies. In K.P. Kallio and S. Mills (eds.), Politics, citizenship and rights, Vol. 7 of T. Skelton (ed.), Geographies of children and young people, Springer, Singapore.

Wu, F. (2016) China's emergent city-region governance: a new form of state spatial selectivity through state-orchestrated rescaling. International Journal of Urban and Regional Research 40.6, 1134-51.

Yiftachel, O. (2015) Epilogue-From 'gray space' to equal 'metrozenship'? Reflections on urban citizenship. International Journal of Urban and Regional Research 39.4, 726-37. 